B. Chevallier

P. Cappelaere

T. Splinter

M. Fabbro

J.L. Wendling

L. Cals

G. Catimel

M. Giovannini

D. Khayat

P. Bastit

N. Claverie

B. Chevallier, M.D. · P. Bastit, M.D. (西) Service d'Oncologie Médicale,

Centre H. Becquerel,

Rue d'Amiens,

F-76038 Rouen, France

P. Cappelaere, M.D

Centre Oscar Lambre, Lille, France

T. Splinter, M.D

University Hospital Dijksigt,

Rotterdam, The Netherlands

M. Fabbro, M.D.

Centre Val d'Aurelle,

Montpellier, France

J.L. Wendling, M.D.

Hôpital Saint-Louis, Toulon, France

L. Cals, M.D.

Hôpital Coste Boyere, La Garde,

Toulon, France

G. Catimel, M.D

Centre Léon Bérard, Lyon, France

M. Giovannini, M.D.

Institut J. Paoli-Calmettes,

Marseille, France

D. Khayat, M.D.

Groupe Hospitalier

de la Pitie-Salpetriere,

Paris, France

N. Claverie, M.D.

Hoechst Marion Roussel, Inc.,

Strasbourg, France

\section{A double-blind, multicentre comparison of intravenous dolasetron mesilate and metoclopramide in the prevention of nausea and vomiting in cancer patients receiving high-dose cisplatin chemotherapy}

ly more effective than metoclopramide for time to first emetic episode, nausea, patient satisfaction, and investigator global assessment of efficacy. Males, chemotherapy-naive patients, and alcoholics had higher response rates. Dolasetron was well tolerated, with mild-to-moderate headache most commonly reported. Twelve percent of patients receiving metoclopramide reported extrapyramidal symptoms compared with $0 \%$ of patients receiving dolasetron. In conclusion, dolasetron mesilate was effective for the prevention of CINV with high-dose cisplatin. Single i.v. doses of dolasetron mesilate were more effective than $7 \mathrm{mg} / \mathrm{kg}$ metoclopramide in preventing nausea and vomiting induced by highly emetogenic cisplatin-containing chemotherapy. In addition, $1.8 \mathrm{mg} /$ $\mathrm{kg}$ dolasetron mesilate consistently produced the highest response rates and appears to be the most effective dose for further clinical development.

Key words Dolasetron Antiemetic - Cisplatin . Metoclopramide $\cdot 5-\mathrm{HT}_{3}$ receptor antagonist

\section{Introduction}

Chemotherapy-induced nausea and vomiting are a primary concern in the treatment of patients with cancer, since uncontrolled nausea and emesis can result in serious medical complications, poor quality of life, and a potentially life-threatening failure to continue treatment $[9,28]$. 
High-dose metoclopramide (7-10 mg/kg per day) has been shown to be effective as a single agent in the treatment of cisplatin-induced emesis $[16,17]$ and has been shown to be effective when administered as a continuous infusion [40]. Metoclopramide-based combination antiemetic therapies have further improved the emesis associated with cisplatin-containing chemotherapy $[14,25,36]$. However, none of these combination regimens is fully effective. Furthermore, owing to its antidopaminergic properties, metoclopramide is frequently associated with unwanted and disabling extrapyramidal reactions, and anxiety and depression $[2,4$, $16,39]$.

The potent serotonin receptor $\left(5-\mathrm{HT}_{3}\right)$ antagonists are new, highly selective agents for the prevention and control of nausea and vomiting after cytotoxic chemotherapy $[15,22]$. These compounds have been shown to be comparable to or more effective than traditional metoclopramide regimens $[1,18,30,37]$, and their use is not accompanied by distressing extrapyramidal side effects $[19,22]$. Some of these new agents also offer the convenience of once-daily dosing and can be then administered in a single i.v. dose [15].

Dolasetron mesilate (Anzemet, Hoechst Marion Roussel) is a new pseudopelletierine-derivative that is highly selective for $5-\mathrm{HT}_{3}$ receptors and is a potent 5$\mathrm{HT}_{3}$ receptor antagonist $[6,13,32]$. Dolasetron is rapidly and almost completely metabolized to a more potent and more selective metabolite (MDL 74,156) that has a longer half-life than the parent compound [5, 7]. Development of dolasetron dosing was based on the mesilate salt. Therefore, all references to doses reflect that of the salt and can be adjusted to the equivalent base by multiplying by 0.74 ; thus, the dolasetron mesilate doses of 1.8 and $2.4 \mathrm{mg} / \mathrm{kg}$ are equivalent to 0.9 and $1.3 \mathrm{mg} / \mathrm{kg}$, respectively. Dose-ranging studies have suggested that i.v. dolasetron has substantial antiemetic effects and is well tolerated by patients receiving moderately or highly emetogenic chemotherapy $[8,23,24,27$, 31]. These studies also showed that the dose with maximal antiemetic activity was a single i.v. dose of $1.8 \mathrm{mg} /$ $\mathrm{kg}$, and that efficacy did not increase substantially with higher single i.v. doses.

Double-blind, randomized trials in patients undergoing high-dose cisplatin-containing chemotherapy have confirmed dose-ranging results $[3,21,41]$. Patients who received a single $1.8 \mathrm{mg} / \mathrm{kg}$ dose of dolasetron mesilate achieved significantly higher rates of complete response (no emetic episodes and no escape antiemetic medication), complete or major response ( $\leq 2$ emetic episodes and no escape antiemetic medication), and significantly longer times to the first emetic episode than those who received $0.6 \mathrm{mg} / \mathrm{kg}$ [41]. Furthermore, another study [21] demonstrated that a single i.v. $1.8 \mathrm{mg} / \mathrm{kg}$ dose of dolasetron mesilate was more efficacious than $0.6 \mathrm{mg} / \mathrm{kg}$ administered three times per day.
Our study compared two different i.v. doses of dolasetron mesilate with metoclopramide in a three-arm, double-blind, randomized parallel study with three major objectives. The first was to determine whether single-dose dolasetron mesilate $(1.2 \mathrm{mg} / \mathrm{kg}$ or $1.8 \mathrm{mg} / \mathrm{kg})$ was as effective as or more effective than the approved regimen of metoclopramide $(3 \mathrm{mg} / \mathrm{kg}$ i.v. loading dose followed by a continuous 8-h infusion of $4 \mathrm{mg} / \mathrm{kg}$ ) in preventing emesis caused by high-dose cisplatin. The second was to compare the tolerability of dolasetron and metoclopramide, and the third was to compare patient satisfaction with each of the three antiemetic regimens.

\section{Patients and methods}

\section{Patients}

From January 1992 to February 1994, 226 male and female cancer patients receiving cisplatin-containing chemotherapy were enrolled at 13 centres throughout Europe. At 12 of these centres, patients received cisplatin at a dose of $\geq 80 \mathrm{mg} / \mathrm{m}^{2}$ over $3 \mathrm{~h}$; at one centre, patients received $70 \mathrm{mg} / \mathrm{m}^{2}$ cisplatin over $4 \mathrm{~h}$. Both chemotherapy-naive patients and those who had previously received cytotoxic chemotherapy were admitted into the study. The protocol for this study was approved by the appropriate institutional review boards and all patients gave written informed consent.

Patients were excluded from the study if they had a history of significant neurological or psychiatric illness (except alcoholism), a history of congestive heart failure, arrhythmias requiring medication, heart block greater than first degree, cardiotoxicity from cumulative doses of anthracyclines/anthracenediones, abnormal serum potassium or calcium concentrations, or evidence of liver disease. Patients who had received investigational drugs within 21 days of the study, chemotherapy in the $72 \mathrm{~h}$ before cisplatin, and treatments that might interfere with the study results were also excluded from the trial. In addition, patients were disqualified if they experienced severe nausea or vomiting (severity of 2-4 according to the Southwest Oncology Group scale) within $24 \mathrm{~h}$ before chemotherapy, as were those who experienced vomiting from any organic aetiology.

\section{Study procedures}

After pretreatment screening, eligible patients were stratified by gender and prior chemotherapy history (naive, non-naive) and randomly assigned to treatment. Patients received either $1.2 \mathrm{mg} /$ $\mathrm{kg}$ or $1.8 \mathrm{mg} / \mathrm{kg}$ dolasetron mesilate as a single i.v. dose over $15 \mathrm{~min}$, beginning $30 \mathrm{~min}$ before cisplatin, or metoclopramide $(3 \mathrm{mg} / \mathrm{kg}$ i.v. loading dose over $15 \mathrm{~min}, 30 \mathrm{~min}$ before cisplatin, followed by $4 \mathrm{mg} / \mathrm{kg}$ as a continuous 8 -h infusion beginning at the same time as cisplatin).

To maintain the blind nature of the study, each test drug was diluted with sterile $0.9 \% \mathrm{NaCl}$ so that each patient received a total infusion of $50 \mathrm{ml}$. In addition, a double-dummy administration technique was used. The first administration of metoclopramide $(3 \mathrm{mg} / \mathrm{kg}$ ) or dolasetron mesilate $(1.2$ or $1.8 \mathrm{mg} / \mathrm{kg}$ ) began $30 \mathrm{~min}$ before the cisplatin infusion and consisted of a $50 \mathrm{ml}$ i.v. infusion over a period of $15 \mathrm{~min}$. On the basis of body weight requirements $(\leq 100 \mathrm{~kg}$ ), it was known that not more than two ampules of dolasetron or placebo and not more than two ampules of me- 
toclopramide or placebo would be used for an individual patient The second administration of metoclopramide $(4 \mathrm{mg} / \mathrm{kg}$ ) or placebo began at the same time as cisplatin administration and consisted of a $500 \mathrm{ml}$ i.v. infusion over a period of $8 \mathrm{~h}$. Additional chemotherapy could be given during the $24 \mathrm{~h}$ following the start of cisplatin administration.

\section{Evaluation of efficacy}

All evaluations for efficacy were made during a 24-h evaluation period measured from the initiation of cisplatin infusion (hour 0 ). The number and timing of emetic episodes during the evaluation period were recorded. An emetic episode was defined as one occurrence of vomiting or a sequence of occurrences in very close succession not relieved by a period of relaxation, any number of occurrences of unproductive emesis (retching) in a single 5-min period, or an episode of retching of less than 5 min duration combined with vomiting that was not relieved by a period of relaxation.

Antiemetic efficacy was evaluated according to the following criteria: complete response was defined as no emetic episodes and no use of escape antiemetic medication, and treatment failure was recorded for any patient who had three or more emetic episodes or needed escape antiemetic medication during the $24 \mathrm{~h}$ after the start of chemotherapy. A patient who was not evaluated for emesis for $24 \mathrm{~h}$ after the start of chemotherapy was also categorized as a treatment failure. In addition, the time to the first emetic episode and the time to escape antiemetic medication were recorded.

Patients assessed the severity of nausea $45 \mathrm{~min}$ before, immediately before, and $24 \mathrm{~h}$ after the start of cisplatin infusion (hour 0 ) according to a visual analogue scale (VAS) that ranged from "no nausea" $(0 \mathrm{~mm})$ to "nausea as bad as it can be" $(100 \mathrm{~mm})$. At hour 24, patients rated their most severe episode of nausea over the 24-h evaluation period. Patient satisfaction was also evaluated according to a VAS ranging from "not at all satisfied" $(0 \mathrm{~mm})$ to "completely satisfied" $(100 \mathrm{~mm})$. In addition, investigators reported their global assessment of efficacy according to a rating scale of 0 to 3 (no, slight, good, excellent efficacy), and the patient's most severe nausea during the $24-\mathrm{h}$ evaluation period according to a discrete scale of 0 to 3 (no, slight, moderate, severe nausea).

\section{Evaluation of safety}

Physical examinations and clinical laboratory tests were performed prior to treatment and at hour 24 . Vital signs were assessed $15 \mathrm{~min}$ before the administration of study medication and at 0.5 , 4,8 , and $24 \mathrm{~h}$ after the start of cisplatin. Electrocardiograms (ECGs), obtained within 3 days before treatment, were repeated at hour 24 in centres that could accommodate this test. Although other studies have demonstrated clinically unimportant, asymptomatic alterations in ECG parameters with dolasetron treatment $[23,41]$, the minimal cardiac monitoring in this study could not be used to make judgements on ECG alterations from dolasetron. All patients were monitored for adverse events throughout the 24-h treatment period.

\section{Statistical analyses}

A sample size of 100 patients per treatment group was estimated as described previously [34], and based on $\alpha=0.05, \beta=0.20$, and an assumed complete response rate of $40 \%$ for the metoclopram- ide group and a $60 \%$ complete response rate for the dolasetron mesilate $1.8 \mathrm{mg} / \mathrm{kg}$ group. A difference of $20 \%$ in the response rates between treatment group was necessary for a conclusion of superiority. Because of slow recruitment, enrollment was terminated with $226 / 300$ patients enrolled. Baseline patient characteristics were compared among treatment groups by the Kruskal-Wallis one-way analysis of variance for quantitative variables and the Chi-square or Fisher's exact test for categorical variables.

The primary test of efficacy was a pairwise comparison between dolasetron mesilate $1.8 \mathrm{mg} / \mathrm{kg}$ and metoclopramide. Pairwise tests of dolasetron mesilate $1.2 \mathrm{mg} / \mathrm{kg}$ versus metoclopramide and $1.2 \mathrm{mg} / \mathrm{kg}$ dolasetron mesilate versus $1.8 \mathrm{mg} / \mathrm{kg}$ dolasetron mesilate were also conducted. Complete response rates were compared by logistic regression with confidence intervals for the odds ratio controlling for stratum (gender, prior chemotherapy status) and investigator. Logistic regression and a main effect test were used to test for differences in response rates across strata. Pairwise confidence intervals and hypothesis tests were used to test for differences between treatment groups. Complete plus major response rates were also assessed by the logistic regression method.

Secondary efficacy analyses included: Cox regression analysis of time to first emesis or use of escape antiemetic medication; rank analysis of covariance for patient nausea VAS and overall patient satisfaction VAS; and, a Mantel-Haenszel raw mean score difference test for analyses of investigator global assessment of efficacy and rating of patients' "most severe nausea".

\section{Results}

\section{Patients}

A total of 300 patients ( 100 per arm) were intended to be recruited for the study, but as the study progressed, antiemetic combination regimens using $5-\mathrm{HT}_{3}$ antagonists became more widely used. Because the new $5-\mathrm{HT}_{3}$ antagonists were preferable to metoclopramide, patient enrollment slowed or stopped and the study was conducted with a total of 226 patients, 225 of whom were included in the intent-to-treat population ( 1 patient dropped out as the result of a serious adverse event following the administration of study medication but prior to receiving chemotherapy); 218 were evaluable for efficacy (6 patients received medications with antiemetic activity and 1 patient had anticipatory vomiting).

The demographic characteristics for patients enrolled at 13 European centres are shown in Table 1. There were no statistically significant differences between the three treatment groups with respect to gender, age, height, weight, or Karnofsky performance status. Overall, the patient population consisted mainly of men $(71 \%)$ and mean ages ranged between 54 and 56 years in the three treatment groups. Head and neck, digestive, and gynaecological neoplasms were the most prevalent. There were also no statistically significant differences across treatment groups with respect to prior use of chemotherapeutic agents, cisplatin dose and duration of cisplatin infusion. The mean cisplatin dose for each of the groups was $92.2 \mathrm{mg} / \mathrm{m}^{2}$ (range: 60$105 \mathrm{mg} / \mathrm{m}^{2}$ ) for the $1.2 \mathrm{mg} / \mathrm{kg}$ dolasetron mesilate 
Table 1 Demographic and baseline characteristics

\begin{tabular}{|c|c|c|c|c|}
\hline Characteristic & $\begin{array}{l}\text { Dolasetron } \\
\text { mesilate } \\
1.2 \mathrm{mg} / \mathrm{kg} \\
(n=84)\end{array}$ & $\begin{array}{l}\text { Dolasetron } \\
\text { mesilate } \\
1.8 \mathrm{mg} / \mathrm{kg} \\
(n=73)\end{array}$ & $\begin{array}{l}\text { Metoclopramide } \\
7 \mathrm{mg} / \mathrm{kg} \\
(n=69)\end{array}$ & $P$ value \\
\hline \multicolumn{5}{|l|}{ Gender (\%) } \\
\hline Male & $56(67)$ & $52(71)$ & $52(75)$ & \multirow[t]{2}{*}{0.498} \\
\hline Female & $28(33)$ & $21(29)$ & $17(25)$ & \\
\hline \multicolumn{5}{|l|}{ Age(years) } \\
\hline Mean \pm SD & $55 \pm 12$ & $54 \pm 10$ & $56 \pm 9$ & 0.380 \\
\hline \multicolumn{5}{|l|}{ Weight (kg) } \\
\hline Mean \pm SD & $64 \pm 12$ & $62 \pm 13$ & $62 \pm 11$ & - \\
\hline \multicolumn{5}{|l|}{ Height (cm) } \\
\hline Mean \pm SD & $168 \pm 8$ & $169 \pm 9$ & $169 \pm 9$ & 0.769 \\
\hline Mean \pm SD & $85 \pm 13$ & $84 \pm 13$ & $81 \pm 12$ & 0.773 \\
\hline $\begin{array}{l}\text { Male naive } \\
\text { Mas (7o) }\end{array}$ & \multicolumn{4}{|c|}{ Prior chemotherapy (\%) } \\
\hline Female naive & $11(13 \%)$ & $9(12 \%)$ & $\begin{array}{l}27(39 \%) \\
10(14 \%)\end{array}$ & \multirow{3}{*}{0.720} \\
\hline Male non-naive & $26(31 \%)$ & $21(29 \%)$ & $25(36 \%)$ & \\
\hline Female non-naive & $17(20 \%)$ & $12(16 \%)$ & $7(10 \%)$ & \\
\hline Site of primary neoplasm & & & & 0.842 \\
\hline Breast & 3 & 4 & 2 & \\
\hline Gastrointestinal & 17 & 17. & 15 & \\
\hline Epidermal & 1 & 0 & 0 & \\
\hline Genitourinary & 6 & 3 & 3 & \\
\hline Gynaecological & 14 & 10 & 8 & \\
\hline Head/neck & 24 & 23. & 24 & \\
\hline Musculoskeletal & 3 & 3 & 1 & \\
\hline Respiratory & 9 & 12 & 12 & \\
\hline Unknown & 7 & 1 & 4 & \\
\hline
\end{tabular}

group, $95.0 \mathrm{mg} / \mathrm{m}^{2}$ (range: $80-120 \mathrm{mg} / \mathrm{m}^{2}$ ) for the $1.8 \mathrm{mg} / \mathrm{kg}$ dolasetron mesilate group and $94.4 \mathrm{mg} / \mathrm{m}^{2}$ (range: $60-120 \mathrm{mg} / \mathrm{m}^{2}$ ) for the metoclopramide group.

Most $(209 / 225$ or $93 \%)$ of the patients received other anticancer agents in addition to cisplatin. Fluorouracil $(56 \%)$, etoposide $(21 \%)$, and cyclophosphamide $(12 \%)$ were the most frequently administered. Statistically significant $(P=0.025)$ differences in the percentage of patients receiving additional chemotherapy were noted across treatment groups; $96 \%, 87 \%$, and $97 \%$ for metoclopramide, $1.2 \mathrm{mg} / \mathrm{kg}$ dolasetron mesilate, and $1.8 \mathrm{mg} / \mathrm{kg}$ dolasetron mesilate, respectively. However, there were no significant differences across treatment groups with respect to the use of specific agents.

\section{Efficacy evaluations}

Efficacy determinations for the three antiemetic treatments are summarized in Table 2. Complete responses were achieved by $57 \%$ of patients in the $1.8 \mathrm{mg} / \mathrm{kg}$ dolasetron mesilate group, $48 \%$ of those in the $1.2 \mathrm{mg} / \mathrm{kg}$ dolasetron mesilate group and, $35 \%$ of those treated with metoclopramide. Both doses of dolasetron were significantly more effective than metoclopramide in preventing cisplatin-induced emesis $(P=0.0009$ for $1.8 \mathrm{mg} / \mathrm{kg}$ dolasetron mesilate versus metoclopramide, $P=0.0058$ for $1.2 \mathrm{mg} / \mathrm{kg}$ dolasetron mesilate versus me- toclopramide). In addition, there was no statistically significant difference between the proportion of complete responses produced by the two dolasetron mesilate doses $(P=0.4733)$.

The median time to first emetic episode or use of escape antiemetic medication was $>24.0,22.5$, and $5.5 \mathrm{~h}$ for patients treated with $1.8 \mathrm{mg} / \mathrm{kg}$ dolasetron mesilate, $1.2 \mathrm{mg} / \mathrm{kg}$ dolasetron mesilate, and metoclopramide, respectively (Table 2). Both dolasetron mesilate doses were significantly superior to metoclopramide $(P=0.0003$ for $1.8 \mathrm{mg} / \mathrm{kg}$ dolasetron mesilate, $P=0.0001$ for $1.2 \mathrm{mg} / \mathrm{kg}$ dolasetron mesilate). The two dolasetron mesilate doses were statistically similar with respect to time to first emetic episode.

There was a significant $(P=0.002)$ difference in complete response rates across and within strata (Table 3). Men $(56 \%, 89 / 160)$ had significantly $(P=0.0001)$ higher complete response rates than women $(25 \%, 16 /$ $65)$. In addition, significantly $(P=0.0448)$ higher rates of complete response were observed in chemotherapynaive patients $(53 \%, 63 / 118)$ than in those who had received prior chemotherapy (39\%, 42/107). Subgroup analyses also indicated that history of alcohol abuse was associated with a higher overall level of response $(P=0.0022)$. Patients with no history of alcohol abuse had an overall complete response rate of $36 \%$, whereas those with a history of alcoholism had a $70 \%$ complete response rate. The response rates within strata were 
Table 2 Efficacy of dolasetron and metoclopramide for prevention of cisplatin-induced emesis

\begin{tabular}{|c|c|c|c|c|c|}
\hline Response $^{\mathrm{a}}$ & $\begin{array}{l}\text { Dolasetron } \\
\text { mesilate } \\
1.2 \mathrm{mg} / \mathrm{kg} \\
(n=84)\end{array}$ & $\begin{array}{l}\text { Dolasetron } \\
\text { mesilate } \\
1.8 \mathrm{mg} / \mathrm{kg} \\
(n=72)\end{array}$ & $\begin{array}{l}\text { Metoclopramide } \\
7 \mathrm{mg} / \mathrm{kg} \\
(n=69)\end{array}$ & $\begin{array}{l}P \text { value } \\
1.8 \mathrm{mg} / \mathrm{kg} \\
\text { vs } \\
\text { metoclopramide }\end{array}$ & $\begin{array}{l}P \text { value } \\
1.2 \mathrm{mg} / \mathrm{kg} \\
\text { vs } \\
\text { metoclopramide }\end{array}$ \\
\hline Complete & $48 \%$ & $57 \%$ & $35 \%$ & 0.0009 & 0.0058 \\
\hline $\begin{array}{l}\text { Median time } \\
\text { to first emetic } \\
\text { episode }(\mathrm{h})\end{array}$ & 22.5 & $>24.0$ & 5.5 & 0.0003 & 0.0001 \\
\hline
\end{tabular}

${ }^{\text {a }}$ Complete response $=$ no emetic episodes and no escape antiemetic medication; treatment failure $=\geq 3$ emetic episodes and/or escape antiemetic medication

Table 3 Complete response rates by strata

\begin{tabular}{llccc}
\hline Stratum & & $\begin{array}{l}\text { Dolasetron } \\
\text { mesilate } \\
1.2 \mathrm{mg} / \mathrm{kg} \\
(n=84)\end{array}$ & $\begin{array}{l}\text { Dolasetron } \\
\text { mesilate } \\
1.8 \mathrm{mg} / \mathrm{kg} \\
(n=72)\end{array}$ & $\begin{array}{l}\text { Metoclopramide } \\
7 \mathrm{mg} / \mathrm{kg} \\
(n=69)\end{array}$ \\
\hline Male naive & $(n=88)$ & $19 / 30(63)$ & $22 / 31(71)$ & $10 / 27(37)$ \\
Male non-naive & $(n=72)$ & $14 / 26(54)$ & $13 / 21(62)$ & $11 / 25(44)$ \\
Female naive & $(n=30)$ & $5 / 11(45)$ & $4 / 9(44)$ & $3 / 10(30)$ \\
Female non-naive & $(n=35)$ & $2 / 17(12)$ & $2 / 11(18)$ & $0 / 7(0)$ \\
All strata & $(n=225)$ & $40 / 84(48)$ & $41 / 72(57)$ & $24 / 69(35)$ \\
\hline
\end{tabular}

Table 4 Control of nausea assessed by visual analogue scale

\begin{tabular}{llllll}
\hline Assessment & $\begin{array}{l}\text { Dolasetron } \\
\text { mesilate } \\
1.2 \mathrm{mg} / \mathrm{kg}\end{array}$ & $\begin{array}{l}\text { Dolasetron } \\
\text { mesilate } \\
1.8 \mathrm{mg} / \mathrm{kg}\end{array}$ & $\begin{array}{l}\text { Metoclopramide } \\
7 \mathrm{mg} / \mathrm{kg}\end{array}$ & $\begin{array}{l}P \text { value } \\
1.8 \mathrm{mg} / \mathrm{kg} \\
\text { vs } \\
\text { metoclopramide }\end{array}$ & $\begin{array}{l}P \text { value } \\
1.2 \mathrm{mg} / \mathrm{kg} \\
\text { vs } \\
\text { metoclopramide }\end{array}$ \\
\hline $\begin{array}{l}\text { Patient assessment } \\
\text { (\% with no nausea over } 24 \mathrm{~h})\end{array}$ & 37 & 51 & 33 & 0.019 & 0.139 \\
$\begin{array}{l}\text { Investigator } \\
\text { assessment of maximum nausea } \\
(\% \text { with no nausea) }\end{array}$ & 38 & 51 & 29 & 0.002 & 0.049 \\
\hline
\end{tabular}

similar to those across strata. Overall, dolasetron mesilate $1.8 \mathrm{mg} / \mathrm{kg}$ was more effective than dolasetron mesilate $1.2 \mathrm{mg} / \mathrm{kg}$, which was more effective than metoclopramide.

Patients' overall assessment of nausea and investigators' assessment of patients' maximum severity of nausea by VAS are summarized in Table 4. The percentage of patients reporting "no nausea" at the 24-h VAS was $50 \%$ for the $1.8 \mathrm{mg} / \mathrm{kg}$ dolasetron mesilate group, $37 \%$ for the $1.2 \mathrm{mg} / \mathrm{kg}$ dolasetron mesilate group, and $33 \%$ for the metoclopramide group. Dolasetron mesilate $1.8 \mathrm{mg} / \mathrm{kg}$ was significantly $(P=0.019)$ more effective than metoclopramide in controlling nausea. Investigator assessment of patients' maximum level of nausea supported this finding $(P=0.002,1.8 \mathrm{mg} / \mathrm{kg}$ dolasetron mesilate versus metoclopramide). More than $50 \%$ of the patients randomized to receive metoclopramide were rated by the investigators as having moderate or severe nausea.

Overall patient satisfaction with treatment and investigators' global assessment of antiemetic efficacy are shown in Table 5. Patients and investigators favoured dolasetron over metoclopramide for both analyses. Both dolasetron mesilate doses demonstrated statistically significant superiority $(P<0.05)$ to metoclopramide in each instance.

\section{Safety}

There were no statistically significant differences in the overall incidence of adverse effects between the dolasetron mesilate $1.2 \mathrm{mg} / \mathrm{kg}(46 \%, 39 / 84)$, dolasetron mesilate $1.8 \mathrm{mg} / \mathrm{kg}(53 \%, 39 / 73)$, and metoclopramide $(61 \%$, 
Table 5 Patient satisfaction and investigator global assessment of efficacy

\begin{tabular}{llllll}
\hline Assessment & $\begin{array}{l}\text { Dolasetron } \\
\text { mesilate } \\
1.2 \mathrm{mg} / \mathrm{kg}\end{array}$ & $\begin{array}{l}\text { Dolasetron } \\
\text { mesilate } \\
1.8 \mathrm{mg} / \mathrm{kg}\end{array}$ & $\begin{array}{l}\text { Metoclopramide } \\
7 \mathrm{mg} / \mathrm{kg}\end{array}$ & $\begin{array}{l}P \text { value } \\
1.8 \mathrm{mg} / \mathrm{kg} \\
\text { vs } \\
\text { metoclopramide }\end{array}$ & $\begin{array}{l}P \text { value } \\
1.2 \mathrm{mg} / \mathrm{kg} \\
\text { vs } \\
\text { metoclopramide }\end{array}$ \\
\hline $\begin{array}{l}\text { Patient satisfaction: } \\
\text { mean score (mm) on VAS }\end{array}$ & 59 & 73 & 54 & 0.002 & 0.0457 \\
$\begin{array}{c}\text { Nivestigator's global } \\
\text { assessment of efficacy } \\
\text { (\% excellent) }\end{array}$ & 36 & 42 & 20 & 0.006 & 0.049 \\
\hline
\end{tabular}

\footnotetext{
${ }^{a}$ Visual analogue scale measured on a $100-\mathrm{mm}$ scale, with 0 indicating "not at all satisfied" and 100 indicating "completely satis-

${ }^{\mathrm{b}}$ Measured on a scale of $0=$ none, $1=$ slight, $2=$ good, and $3=\mathrm{ex}$ fied" cellent
}

Table 6 Summary of adverse events reported by $\geq 3 \%$ of patients $^{\mathrm{a}}$

\begin{abstract}
${ }^{a}$ Values represent number $(\%)$ of patients reporting an adverse event
\end{abstract}

\begin{tabular}{llll}
\hline Event & $\begin{array}{l}\text { Dolasetron } \\
\text { mesilate } \\
1.2 \mathrm{mg} / \mathrm{kg} \\
(n=84)\end{array}$ & $\begin{array}{l}\text { Dolasetron } \\
\text { mesilate } \\
1.8 \mathrm{mg} / \mathrm{kg} \\
(n=73)\end{array}$ & $\begin{array}{l}\text { Metoclopramide } \\
7 \mathrm{mg} / \mathrm{kg} \\
(n=69)\end{array}$ \\
\hline Headache & $10(12)$ & $13(18)$ & $4(6)$ \\
Diarrhoea & $10(12)$ & $10(14)$ & $13(19)$ \\
Hypertension & $2(2)$ & $8(11)$ & $9(13)$ \\
Hepatic dysfunction & $6(7)$ & $1(1)$ & $1(1)$ \\
Abdominal pain & $1(1)$ & $2(3)$ & $3(4)$ \\
Hypotension & 0 & $3(4)$ & $2(3)$ \\
Increased sweating & $3(4)$ & 0 & $2(3)$ \\
Hot flushes & $2(2)$ & 0 & $3(4)$ \\
\hline
\end{tabular}

42/69) treatment groups. Adverse events were generally mild to moderate in intensity. Overall, the most frequently reported adverse events were headache $(12 \%$, $27 / 226)$, diarrhoea $(16 \%, 36 / 226)$, and hypertension $(8 \%, 19 / 226)$.

As shown in Table 6 , mild to moderate headache was more frequent in the dolasetron groups $(15 \%, 23 /$ 157 overall; $18 \%, 13 / 73$ in the $1.8 \mathrm{mg} / \mathrm{kg}$ group; $12 \%$, $10 / 84$ in the $1.2 \mathrm{mg} / \mathrm{kg}$ group) than in the metoclopramide group $(6 \%, 4 / 69)$, but these differences were not statistically significant. Gastrointestinal events were more frequent in the metoclopramide group (35\%, 24/ $69)$ than in the dolasetron groups $(22 \%, 34 / 157)$. Diarrhoea, the most common gastrointestinal adverse event, was reported in $22 \%(15 / 69)$ of those receiving metoclopramide, compared with only $12 \%(10 / 84)$ of patients receiving $1.2 \mathrm{mg} / \mathrm{kg}$ dolasetron mesilate and $15 \%$ $(11 / 73)$ of those receiving $1.8 \mathrm{mg} / \mathrm{kg}$ dolasetron mesilate. Hypertension was observed in $2 \%(2 / 84 ; 1$ mild, 1 severe) of patients in the $1.2 \mathrm{mg} / \mathrm{kg}$ dolasetron mesilate group, $11 \%(8 / 73 ; 7$ mild, 1 moderate $)$ of patients in the $1.8 \mathrm{mg} / \mathrm{kg}$ dolasetron mesilate group, and $13 \%(9 / 69 ; 7$ mild, 2 moderate) of patients in the metoclopramide group.
Eight patients in the metoclopramide group experienced adverse events that could be regarded as extrapyramidal effects, including extrapyramidal disorder (1 patient), shaking (1 patient), slurred speech (2 patients), stiff jaw ( 2 patients), thick tongue (1 patient), and tremor (1 patient). No such events were reported in either of the dolasetron-treated groups of patients.

Overall, 16 patients experienced severe adverse events. These included 7 patients in the metoclopramide group, 6 patients in the dolasetron mesilate $1.2 \mathrm{mg} /$ $\mathrm{kg}$ group, and 3 patients in the dolasetron mesilate $1.8 \mathrm{mg} / \mathrm{kg}$ group. Three deaths occurred in this study, outside the 24 -h treatment period, in patients who were randomized to receive $1.2 \mathrm{mg} / \mathrm{kg}$ dolasetron mesilate. These deaths resulted from dyspnoea, septic shock, and acute renal failure and were attributed to progression of the patients' primary neoplasm or to events secondary to cancer by the investigator. One patient who received dolasetron developed severe hypotension. This patient later developed other cardiac symptoms, including hypotension and pulmonary oedema, during other chemotherapy cycles. The severe hypotension was not considered to be related to dolasetron treatment. 


\section{Discussion}

This prospective, randomized trial demonstrated dolasetron to be superior to metoclopramide in the prevention of cisplatin-induced emesis. Patients who received single i.v. doses of 1.2 and $1.8 \mathrm{mg} / \mathrm{kg}$ dolasetron mesilate had higher complete response rates, lower failure rates, and longer median times to first emesis during the study than patients who received metoclopramide.

Complete responses were achieved by $57 \%$ of patients in the dolasetron mesilate $1.8 \mathrm{mg} / \mathrm{kg}$ group, $48 \%$ of patients in the dolasetron mesilate $1.2 \mathrm{mg} / \mathrm{kg}$ group, and $35 \%$ of patients in the metoclopramide group. The complete response rates in this study were similar to those reported in other trials using a single i.v. dose of $1.8 \mathrm{mg} / \mathrm{kg}$ of dolasetron mesilate for the prevention of cisplatin-induced emesis [3, 21, 41]. In addition, the complete response rates observed were also consistent with rates reported for other single-agent $5-\mathrm{HT}_{3}$ antagonist regimens $[1,12,29]$ and for metoclopramide $[14$, $20,30]$ in patients undergoing highly emetogenic chemotherapy. In this study, $1.8 \mathrm{mg} / \mathrm{kg}$ dolasetron mesilate was clearly superior to metoclopramide for all antiemetic endpoints.

It is well documented that patients receiving cisplatin without antiemetic support experience their most intense emesis during the first $6 \mathrm{~h}$ after treatment [10]. The marked difference between dolasetron and metoclopramide with respect to median time to first emetic episode $-5.5 \mathrm{~h}$ for metoclopramide, $22.5 \mathrm{~h}$ for $1.2 \mathrm{mg} /$ $\mathrm{kg}$ dolasetron mesilate and $>24 \mathrm{~h}$ for $1.8 \mathrm{mg} / \mathrm{kg}$ dolasetron mesilate - again demonstrates the superiority of dolasetron over metoclopramide for control of emesis in this group of patients. Patients also noted a marked preference for dolasetron over metoclopramide according to VAS assessments of satisfaction with overall antiemetic control and control of nausea. The superiority of $1.8 \mathrm{mg} / \mathrm{kg}$ dolasetron mesilate over metoclopramide was also reflected in the investigators' global assessment of efficacy and their ratings of patients' most severe episode of nausea.

When the present study was initiated, high-dose metoclopramide was an integral part of effective antiemetic combination therapy [26], despite its capacity for induction of extrapyramidal reactions, particularly in adolescents. However, as the study progressed, a number of new $5-\mathrm{HT}_{3}$ receptor antagonists received approval in Europe for the prevention of emesis in patients receiving cytotoxic chemotherapy. Because these agents had a more acceptable adverse event profile than metoclopramide, they were more attractive to patients and investigators than previous standard therapy. As a consequence, patient enrollment into this study slowed dramatically and patient recruitment was terminated early. Nevertheless, the total number of patients enrolled (226) is large enough to give the study sufficient power to distinguish statistically between the three treatment arms.

It has been shown that the effectiveness of antiemetic agents in controlling chemotherapy-induced emesis and nausea varies not only according to the antiemetic regimen used but also according to patient characteristics. Nausea and vomiting may be more severe or harder to prevent in female patients and in those who have had prior chemotherapy $[8,12,15,18]$. To control for these factors, patients in this study were stratified by gender and prior exposure to chemotherapy before randomization. Subgroup analyses showed that complete response rates were up to two times higher for male than for female patients; this difference was consistent across all treatment arms. In addition, when comparisons were made within each gender stratum for chemotherapy-naive versus non-naive patients, responses were more favourable in chemotherapy-naive patients. This difference was particularly marked among female patients. The highest complete response rate $(71 \%)$ was achieved by male chemotherapy-naive patients who received $1.8 \mathrm{mg} / \mathrm{kg}$ dolasetron mesilate and the lowest $(0 \%)$, by female, non-chemotherapynaive patients who received metoclopramide.

Subgroup analyses also demonstrated that prior history of alcohol abuse was a significant predictor of response. Complete response rates were higher in patients with a history of alcoholism than in those without $(P=0.0022)$, a finding that is consistent with results of previous studies $[11,15,18,38]$. No significant differences in treatment response were found in any group when patients were stratified for age, Karnofsky score, or use of narcotic analgesics.

Dolasetron was well tolerated in this study, with adverse events mild to moderate in intensity and similar to those reported for other $5-\mathrm{HT}_{3}$ receptor antagonists $[15,18]$. Headache was most commonly reported, also with similar intensity to that experienced with other 5$\mathrm{HT}_{3}$ antagonists, including ondansetron and granisetron $[15,18,29,33,35]$. Unlike metoclopramide, dolasetron led to no extrapyramidal reactions in either dose group. There were no deaths and no serious adverse events with dolasetron treatment.

In summary, this double-blind, parallel-group study demonstrated that dolasetron is both safer and more effective than metoclopramide in the prevention of emesis and nausea induced by high-dose cisplatin therapy. In addition, $1.8 \mathrm{mg} / \mathrm{kg}$ dolasetron mesilate consistently produced higher response rates than $1.2 \mathrm{mg} / \mathrm{kg}$ dolasetron mesilate or metoclopramide for all antiemetic endpoints and warrants further clinical development.

Acknowledgements The authors acknowledge the editorial assistance of Marc Eisenberg, Ph.D., Gary McQuarrie, Pharm.D., and Neil Malone, M.S. This study was supported by a grant from Hoechst Marion Roussel, Inc. 


\section{References}

1. Aapro MS (1991) 5-HT 3 receptor antagonists. An overview of their present status and future potential in cancer therapy-induced emesis. Drugs 42:551-568

2. Allen JC, Gralla R, Reilly L, et al (1985) Metoclopramide: dose-related toxicity and preliminary antiemetic studies in children receiving cancer chemotherapy. J Clin Oncol 3:11361141

3. Audhuy B, Cappelaere P, Claverie N, et al (1995) Double-blind comparison of the antiemetic efficacy of two single iv doses of dolasetron and one iv dose of granisetron after cisplatin ( $\geq 80 \mathrm{mg} / \mathrm{m}^{2}$ ) chemotherapy (abstract). Support Care Cancer 5:338

4. Bateman DN, Rawlins MD, Simpson JM (1985) Extrapyramidal reactions with metoclopramide. BMJ 291:930932

5. Bigaud M, Elands J, Kastner PR, et al (1995) Pharmacology of the human metabolites of dolasetron, an antiemetic $5-\mathrm{HT}_{3}$ receptor antagonist. Drug Dev Res 34:289-296

6. Boeijinga $\mathrm{PH}$, Galvan $\mathrm{M}$, Baron $\mathrm{BM}$, et al (1992) Characterization of the novel $5-\mathrm{HT}_{3}$ antagonists MDL 73147EF (dolasetron mesylate) and MDL 74156 in NG108-15 neuroblastoma $\times$ glioma cells. Eur J Pharmacol 219:9-13

7. Boxenbaum H, Gillespie T, Heck K, et al (1992) Human dolasetron pharmacokinetics. I. Disposition following single-dose intravenous administration to normal male subjects. Biopharm Drug Dispos 13:693-701

8. Conroy T, Cappelaere P, Fabbro M, et al (1994) Acute antiemetic efficacy and safety of dolasetron mesylate, a $5-\mathrm{HT}_{3}$ antagonist, in cancer patients treated with cisplatin. Am J Clin Oncol 17:97-102

9. Cooper S, Georgiou V (1992) The impact of cytotoxic chemotherapy perspectives from patients, specialists and nurses. Eur J Cancer 28A [Suppl 1]:S36-S38

10. Cunningham D, Soukop M, Gilchrist NL, et al (1985) Randomised trial of intravenous high-dose metoclopramide and intramuscular chlorpromazine in controling nausea and vomiting induced by cytotoxic drugs. BMJ 290:604-605

11. D'Aquisto R, Tyson LB, Gralla RJ, et al (1986) The influence of chronic high alcohol intake on chemotherapyinduced nausea and vomiting (abstract). Proc Am Soc Clin Oncol $5: 257$
12. De Mulder PHM, Seynaeve C, Vermorken JB, et al (1990) Ondansetron compared with high-dose metoclopramide in prophylaxis of acute and delayed cisplatin-induced nausea and vomiting. Ann Intern Med 113:834840

13. Galvan M, Gittos MW, Fatmi M (1993) Dolasetron mesylate. Drugs Future 18:506-509

14. Gordon CJ, Pazdur R, Ziccarelli A, et al (1989) Metoclopramide versus metoclopramide and lorazepam: superiority of combined therapy in the control of cisplatin-induced emesis. Cancer 63:578-582

15. Gralla RJ (1993) Current issues in the management of nausea and vomiting. Ann Oncol 4 [Suppl 3]:S3-S7

16. Gralla RJ, Itri LM, Pisko SE, et al (1981) Antiemetic efficacy of highdose metoclopramide: randomised trials with placebo and prochlorperazine in patients with chemotherapy induced nausea and vomiting. $\mathrm{N}$ Engl J Med 305: 905-909

17. Gralla RJ, Tyson LB, Kris MG, et al (1987) The management of chemotherapy-induced nausea and vomiting. Med Clin North Am 72:289-300

18. Grunberg SM, Hesketh PJ (1993) Control of chemotherapy-induced emesis. N Engl J Med 329:1790-1796

19. Grunberg SM, Stevenson LL, Russell CA, et al (1989) Dose ranging phase I study of the serotonin antagonist GR38032F for prevention of cisplatininduced nausea and vomiting. $\mathbf{J}$ Clin Oncol 7:1137-1141

20. Hainsworth J, Harvey W, Pendergrass $\mathrm{K}$, et al (1991) A single-blind comparison of intravenous ondansetron, a selective serotonin antagonist, with intravenous metoclopramide in the prevention of nausea and vomiting associated with high-dose cisplatin chemotherapy. J Clin Oncol 9:721728

21. Harman GS, Omura GA, Ryan K, Hainsworth JD, Cramer MB, Hahne WF (1996) A randomized, doubleblind comparison of single-dose and divided multiple-dose dolasetron for cisplatin-induced emesis. Cancer Chemother Pharmacol 38:323-328

22. Hesketh PJ (1991) Serotonin antagonists: a new class of antiemetic agents. J Natl Cancer Inst 83:613-620

23. Hesketh PJ, Gandara DR, Hesketh AM, et al (1996) Dose-ranging evaluation of the antiemetic efficacy of intravenous dolasetron in patients receiving chemotherapy with doxorubicin or cyclophosphamide. Support Care Cancer 4:141-146
24. Kirchner V, Aapro M, Alberto P, et al (1993) Early clinical trial of MDL 73,147 EF: a new $5 \mathrm{HT}_{3}$-receptor antagonist for the prevention of chemotherapy-induced nausea and vomiting. Ann Oncol 4:481-484

25. Kris MG, Gralla RJ, Tyson LB, et al (1985) Improved control of cisplatininduced emesis with high-dose metoclopramide and with combinations of metoclopramide, dexamethasone, and diphenhydramine. Results of consecutive trials in 255 patients. Cancer 55:527-534

26. Kris MG, Gralla RJ, Clark RJ, et al (1987) Antiemetic control and prevention of side effects of anticancer therapy with lorazepam or diphenhydramine when used in combination with metoclopramide plus dexamethasone. Cancer 60:2816-2822

27. Kris MG, Grunberg SM, Gralla RJ, et al (1994) Dose-ranging evaluation of the serotonin antagonist dolasetron mesylate in patients receiving highdose cisplatin. J Clin Oncol 12:10451049

28. Lazlo J (1983) Nausea and vomiting as major complications of cancer chemotherapy. Drugs 25 [Suppl 1]:1-7

29. Markham A, Sorkin EM (1993) Ondansetron. An update of its therapeutic use in chemotherapy-induced and postoperative nausea and vomiting. Drugs 45:931-952

30. Marty M, Pouillart P, Scholl S, et al (1990) Comparison of the 5-hydroxytryptamine-3 (serotonin) antagonist ondansetron (GR 38032F) with highdose metoclopramide in the control of cisplatin-induced emesis. $\mathrm{N}$ Engl J Med 322:816-821

31. Merrouche Y, Catimel G, Rebattu P, et al (1994) A phase I antiemetic study of MDL 73,147EF, a novel 5hydroxytryptamine antagonist in cancer patients receiving emetogenic chemotherapy. Ann Oncol 5:549-551

32. Miller RC, Galvan M, Gittos MW, et al (1993) Pharmacological properties of dolasetron, a potent and selective antagonist at $5-\mathrm{HT}_{3}$ receptors. Drug Dev Res 28:87-93

33. Navari RM, Kaplan HG, Gralla RJ, et al (1994) Efficacy and safety of granisetron, a selective 5-hydroxytryptamine- 3 receptor antagonist, in the prevention of nausea and vomiting induced by high-dose cisplatin. $\mathrm{J}$ Clin Oncol 12:2204-2210

34. Peace KM (1990) Statistical issues in drug research and development. Dekker, New York 
35. Riviere A (1994) Dose finding study of granisetron in patients receiving high-dose cisplatin chemotherapy. $\mathrm{Br}$ J Cancer 69:967-971

36. Roila F, Tonato M, Basurto C, et al (1987) Anti-emetic activity of highdose metoclopramide combined with methylprednisolone versus metoclopramide alone in cisplatin-treated cancer patients: a randomized doubleblind trial of the Italian Oncology Group for Clinical Research. J Oncol 5:141-149
37. Sledge GW Jr, Einhorn L, Nagy C, et al (1992) Phase III double-blind comparison of intravenous ondansetron and metoclopramide as antiemetic therapy for patients receiving multiple-day cisplatin-based chemotherapy. Cancer 70:2524-2528

38. Sullivan JR, Leyden MJ, Bell R (1983) Decreased cisplatin induced nausea and vomiting with chronic alcohol ingestion. N Eng1 J Med 309:796-797

39. Tortorice PV, O'Connell MB (1990) Management of chemotherapy-induced nausea and vomiting. Pharmacotherapy $10: 129-145$
40. Warrington PS, Allan SG, Cornbleet MA, et al (1986) Optimising antiemetics in cancer chemotherapy: efficacy of continuous versus intermittent infusion of high-dose metoclopramide in emesis induced by cisplatin. BMJ 293:1334-1337

41. Yielding A, Bertoli L, Eisenberg P, et al (1996) Antiemetic efficacy of two different single intravenous doses of dolasetron in patients receiving highdose cisplatin-containing chemotherapy. Am J Clin Oncol (in press) 